\title{
Mustard (Sinapis) in five-field tilled grain-fallow crop rotations in Southern Russia
}

\author{
$E N$ Turin $^{1, *}, K G$ Zhenchenko $^{1}, A A$ Gongalo $^{1}, V I u$ Ivanov $^{1}, R A$ Kulinich $^{1}, E V$ Remeslo $^{1}$, \\ $E N$ Rostova $^{1}$, and $M V$ Shestopalov $^{2}$ \\ ${ }^{1}$ Research Institute of Agriculture of Crimea, 150 Kievskaya str., Simferopol, Republic of Crimea, \\ 295453 \\ ${ }^{2}$ Academy of life and environmental sciences «V I Verrnadsky Crimean Federal University», 1A, \\ Nauchnaya str., village of Agrarnoye, 295492, Russia
}

\begin{abstract}
The aim of the research was to study the cultivation of Sarepta mustard in the first and white mustard in the second rotation of the crop rotation. The experiments show the yield, its dependence on the timing of sowing mustard, the amount of productive moisture, weediness of crops in the links of crop rotations with mustard and mustard as a precursor. The main tillage in fallow is ploughing, whereas shallow and surface loosening are used for all other crops, including mustard. Mineral fertilizers for mustard were applied in autumn with a dose of $\mathrm{N}_{60} \mathrm{P}_{60}$ for the main tillage. An analysis of the yield by crop rotation with the title field of fallow and clean fallow showed that the average yield of mustard was 1.25 and 1.14 $\mathrm{t} / \mathrm{ha}$, respectively. It follows from this that, in the crop rotation with pure fallow, there was a tendency to increase the yield by 0.1 to $0.5 \mathrm{t} / \mathrm{ha}$ in comparison with the crop rotation where the fallow is occupied, but these increases are mathematically unprovable. The reserves of productive moisture for sowing mustard in crop rotations with the header field of clean and occupied fallow were the same both in the arable and meter horizons.
\end{abstract}

\section{Introduction}

In the steppe zone of the Crimea, which is characterized by extreme aridity, grain-fallow crop rotations with an obligatory field of clean, occupied, or green manure fallow have been widespread in recent decades. At the same time, the grain problem is solved, but in the absence of animal husbandry, and, consequently, organic fertilizers, the preservation of soil fertility is not ensured: the loss of humus increases, soil dehumification occurs, wind blows take place, and with heavy rains and water erosion, the phytosanitary situation of the agrocenosis is aggravated. It is possible to solve these problems relatively quickly by means of tilled grain-fallow crop rotations, that is, by introducing beans, legumes, cruciferous, oilseeds into the crop rotation [1-2]. All these crops, each in its own way, contribute to the

\footnotetext{
* Corresponding author: turin_e@ niishk.ru
} 
stabilization of soil fertility and a stable output of grain and fodder units per hectare of crop rotation area [3-4].

The founder of the pilot business in the Crimea, Professor N.N. Klepinin wrote "Improving field cultivation is possible not only by better tillage, but also by a more correct alternation of crops, mainly by introducing row crops into the crop rotation." Almost a hundred years have passed, and the opinion of the scientist has not lost its relevance [5]. Not the least among the intermediate crops are Sarepta mustard (Brassica juncea), white mustard (Sinapis alba) and black mustard (Brassica nigra). From an agronomic point of view, the introduction of mustard into crop rotation has a positive effect on the agrophysical and agrochemical properties of the soil. Its taproot, penetrating to a depth of 3 $\mathrm{m}$, loosens the soil, therefore, improves its structure, which is especially important when switching to minimizing basic tillage or direct sowing for individual crops. Its roots are able to assimilate sparingly soluble nutrients. They facilitate transfer of those nutrients from deeper soil horizons to the upper ones, where they are used by subsequent plants, most often cereal crops, the predecessors of which are mustard. The presence of mustard in crop rotation contributes to the biological health of the soil in relation to pathogens of fungal and other diseases; the cycle of development of pests and weeds "specializing" in winter cereals is interrupted. Mustard is more competitive against weeds than other row crops such as pulses. In comparison with other oilseeds, mustard is more drought-resistant, resistant to shattering, and has a short growing season [6-8]. Under the conditions of resource-saving agriculture, mustard is successfully sown in green manure fallows as an intermediate crop [9-10].

Recently, there has been an increased interest in mustard produced in the south of Russia [11-13]. It is a valuable oilseed crop, the oil of which is used for food and technical purposes [14-15]. Mustard grown in Crimea, where the climate is close to the Mediterranean, according to experts from Germany, is not inferior in its taste, and even better in some parameters than high-quality Canadian one [16]. Mustard is an excellent honey plant [17].

\section{Research methods and conditions}

The experiments were carried out during two crop rotations (2006-2015) on the experimental field "Scientific Research Institute of Agriculture of the Crimea". Location Southern Crimean Steppe. The relief is a gently undulating plain, 80 to $90 \%$ plowed up. The soil on the experimental field is low-humus southern chernozem, slightly washed off with a humus content in the arable layer of 2.00 to $2.30 \%$ [18]. The climate is characterized by continental, arid, hot. Significant losses are caused by the north-east wind, which contributes to droughts and dry winds; provoking dust storms, in early spring - frosts. [19].

During the period of the experiments, the amount of precipitation varied from $251 \mathrm{~mm}$ (2012) to $620 \mathrm{~mm}$ (2014), with an average long-term indicator of $428 \mathrm{~mm}$. The hydrothermal coefficient is, respectively, from 0.27 to 1.23 with an average long-term indicator of 0.67 .

Sarepta and white mustards are full-fledged crops of five-field grain-fallow crop rotations. Their study was carried out in crop rotations with the following alternation. Crop rotation I - clean fallow, winter wheat, mustard, winter wheat, spring barley and crop rotation II - busy fallow (winter grain legumes), winter wheat, mustard, winter barley, sunflower.

The main cultivation of the soil in pairs is plowing, for all other crops, including for mustard, shallow and surface loosening. Organic fertilizers were applied in a fallow field at the rate of 7 tons per hectare of crop rotation. Mineral fertilizers for mustard were applied in autumn with a dose of $\mathrm{N}_{60} \mathrm{P}_{60}$ for the main tillage. In the spring, they were limited to one 
pre-sowing cultivation at the depth of seeding, i.e. 5-6 cm. Sowing was carried out with treated seeds at a seeding rate of $1.5 \mathrm{million} / \mathrm{ha}$. Chemical treatments of crops were mandatory when the economic threshold of harmfulness of weeds was exceeded.

All agrotechnical measures and research were carried out according to generally accepted methods, recommendations and in accordance with the experimental scheme [20]. Mathematical processing was carried out according to the method of Little and Hills [21].

\section{Research results}

Mustard was the third crop of the crop rotation. The head crop of the crop rotation, either clean fallow or occupied fallow, had little effect on the level of its productivity (Table 1 and Table 2). Nevertheless, there is a tendency for higher yields on average in the crop rotation with clean fallow, both Sarepta and white mustard, by $0.1 \mathrm{t} /$ ha in comparison with occupied fallow.

Table 1. Sarepta mustard yield in first rotation of crop rotation, $\mathrm{t} / \mathrm{ha}$.

\begin{tabular}{|c|c|c|c|c|c|c|}
\hline \multirow{2}{*}{ Crop rotations } & \multicolumn{5}{|c|}{ Years } & $\begin{array}{c}\text { Average per } \\
\text { rotation }\end{array}$ \\
\hline & 2006 & 2007 & 2008 & 2009 & 2010 & \\
\hline I & 1.4 & 0.6 & 2.5 & 0.6 & 1.4 & 1.3 \\
\hline II & 1.3 & 0.6 & 2.4 & 0.6 & 1.3 & 1.2 \\
\hline
\end{tabular}

Table 2. White mustard yield in second rotation of crop rotation, $t /$ ha.

\begin{tabular}{|c|c|c|c|c|c|c|}
\hline \multirow{2}{*}{ Crop rotations } & \multicolumn{5}{|c|}{ Years } & $\begin{array}{c}\text { Average per } \\
\text { rotation }\end{array}$ \\
\hline & 2011 & 2012 & 2013 & 2014 & 2015 & \\
\hline I & 1.3 & 0.9 & 0.2 & 1.1 & 2.0 & 1.1 \\
\hline II & 1.2 & 0.9 & 0.2 & 1.0 & 1.8 & 1.0 \\
\hline
\end{tabular}

In terms of yield parameters, Sarepta mustard averaged 1.3 and $1.2 \mathrm{t} / \mathrm{ha}$ for the first rotation in crop rotations, which is slightly higher than the yield of white mustard in the next rotation. Its yield is $0.2 \mathrm{t} /$ ha higher than that of white mustard. Maybe the weather conditions of the second rotation - the most severe drought in 2012 to 2013 - played a role in this. According to our economists' calculations, with a yield of 0.5 to $0.6 \mathrm{t} / \mathrm{ha}$, mustard becomes a profitable crop. Consequently, on average in rotations and crop rotations, both Sarepta and white mustard were profitable crops.

For ten years of growing mustard, some natural and climatic nuances were observed that had a direct impact on its yield. The calendar sowing dates for mustard were not adhered to, they sowed as early as possible, when the opportunity to go into the field was provided and optimal conditions for sowing were created. It was sown at the same time as early spring cereals or after them. The following goals were pursued: to make fuller use of the moisture accumulated during the winter; avoid damage to seedlings by a cruciferous flea and other pests; compete with late spring weeds.

The influence of sowing time on seedling and yield is presented in table 3 . The highest yield of 2.42 to 2.51 t/ha was obtained in 2008 with sowing in the third decade of February. 
Table 3. Influence of sowing time on mustard yield, t/ha.

\begin{tabular}{|l|c|c|c|c|c|}
\hline \multirow{2}{*}{ Year } & Sowing number & $\begin{array}{c}\text { Number of } \\
\text { seedlings } \\
\end{array}$ & received & \multirow{2}{*}{$\begin{array}{c}\text { Sowing-germination } \\
\text { period }\end{array}$} & \multicolumn{2}{|c|}{$\begin{array}{c}\text { Yield by crop rotation, } \\
\text { t/ha }\end{array}$} \\
\cline { 5 - 6 } & & April 13 & 19 days & 1.38 & II \\
\hline 2006 & March 25 & April 3 & 18 days & 0.60 & 0.56 \\
\hline 2008 & March 16 & March 11 & 16 days & 2.51 & 2.42 \\
\hline 2009 & March 11 & April 3 & 23 days & 0.64 & 0.59 \\
\hline 2010 & February 26 & March 29 & 32 days & 1.37 & 1.27 \\
\hline 2011 & March 17 & April 5 & 19 days & 1.29 & 1.23 \\
\hline 2012 & March 21 & April 9 & 19 days & 0.95 & 0.93 \\
\hline 2013 & February 27 & March 20 & 22 days & 0.21 & 0.19 \\
\hline 2014 & March 5 & March 24 & 19 days & 1.10 & 1.07 \\
\hline 2015 & March 7 & March 27 & 20 days & 2.00 & 1.82 \\
\hline
\end{tabular}

The very early sowing period and the amount of precipitation during the growing season played a role - $196 \mathrm{~mm}$, with an average long-term indicator for the same period - $160 \mathrm{~mm}$. When sowing literally on the same day, but in 2010, the yield is half less - 1.27 and 1.37 t/ha. The long cold period in March affected (frosts on the soil were observed for 18 days out of 31), as a result, seedlings received only a month later, and then the absence of economically useful precipitation for 78 days (February-March-April). The early sowing date did not bring the desired harvest and in 2013 the seedlings obtained on March 20 died as a result of prolonged frosts on March 23 to 24 (from -3.4 to $-6.1^{\circ} \mathrm{C}$ ). Mustard was resown and sprouted, but in April to May precipitation was almost not observed, so they received the lowest yield for 10 years of 0.19 to $0.21 \mathrm{t} / \mathrm{ha}$.

The crop yield in March ranged from 0.56 to 2 t/ha. Sowing yield in March ranged from 0.56 to $2 \mathrm{t} / \mathrm{ha}$. When sowing almost all crops grown in our crop rotations, the presence of productive moisture in the sowing layer of 0 to $10 \mathrm{~cm}$, and even more in the meter layer - 0 to $100 \mathrm{~cm}$ matters. The amount of productive moisture in individual links for crop rotations in the first and second rotations are presented in tables 4 and 5. 
Table 4. Productive moisture reserves in links of crop rotations in first rotation during sowing, $\mathrm{mm}$.

\begin{tabular}{|c|c|c|c|c|c|c|c|c|c|c|c|c|}
\hline \multirow[b]{2}{*}{$\begin{array}{l}\text { Crop } \\
\text { rotation } \\
\text { links }\end{array}$} & \multicolumn{2}{|c|}{2006} & \multicolumn{2}{|c|}{2007} & \multicolumn{2}{|c|}{2008} & \multicolumn{2}{|c|}{2009} & \multicolumn{2}{|c|}{2010} & \multicolumn{2}{|c|}{ Average } \\
\hline & $\frac{0}{0}$ & $\frac{8}{0}$ & $\stackrel{0}{\frac{1}{0}}$ & $\frac{8}{0}$ & $\frac{0}{1}$ & $\frac{8}{0}$ & $\frac{0}{0}$ & $\frac{8}{6}$ & $\frac{0}{d}$ & $\frac{8}{0}$ & $\frac{0}{0}$ & $\frac{8}{6}$ \\
\hline \multicolumn{13}{|c|}{ Crop rotation I } \\
\hline $\begin{array}{l}\text { Winter } \\
\text { wheat } \\
\text { in pure } \\
\text { fallow }\end{array}$ & $\stackrel{n}{=}$ & $\frac{n}{f}$ & $\stackrel{?}{r}$ & $\frac{n}{6}$ & $\underset{\infty}{\stackrel{+}{+}}$ & in & in & is & 0 & $\stackrel{\sim}{\stackrel{0}{0}}$ & $\begin{array}{l}\stackrel{8}{0} \\
\dot{0}\end{array}$ & $\underset{+}{\infty}$ \\
\hline Mustard & $\stackrel{0}{\circ}$ & $\Xi$ & 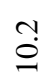 & ๙̊? & n̊? & $\stackrel{\vartheta}{\dot{f}}$ & $\stackrel{\circ}{\stackrel{\Xi}{ \pm}}$ & $\stackrel{\dot{\delta}}{0}$ & $\stackrel{\infty}{=}$ & $\stackrel{8}{ }$ & $\Xi$ & $\vec{\infty}$ \\
\hline $\begin{array}{l}\text { Winter } \\
\text { wheat } \\
\text { for } \\
\text { mustard }\end{array}$ & $\stackrel{\sim}{\stackrel{N}{Z}}$ & $\begin{array}{l}\stackrel{0}{\infty} \\
\stackrel{\infty}{+}\end{array}$ & $\stackrel{\Upsilon}{r}$ & $\stackrel{+}{\stackrel{+}{*}}$ & $\frac{P}{i n}$ & $\vec{\delta}$ & $\begin{array}{l}8 \\
\stackrel{8}{i}\end{array}$ & $\stackrel{n}{\sim}$ & 0 & 0 & $\begin{array}{l}\stackrel{n}{n} \\
\text { in }\end{array}$ & ஜ̊. \\
\hline \multicolumn{13}{|c|}{ Crop rotation II } \\
\hline $\begin{array}{l}\text { Fallow } \\
\text { winter } \\
\text { wheat }\end{array}$ & $\stackrel{N}{\Xi}$ & $\stackrel{n}{\mathfrak{r}}$ & $\stackrel{\sigma}{\infty}$ & $\begin{array}{l}\infty \\
\dot{f} \\
\dot{q}\end{array}$ & ñ & ?n & $\stackrel{0}{6}$ & $\vec{\infty}$ & 0 & $\stackrel{\circ}{\circ}$ & $\begin{array}{l}8 \\
\text { in }\end{array}$ & $\stackrel{\infty}{m}$ \\
\hline Mustard & $\tilde{a}$ & so & aे & n̊? & $\stackrel{0}{\circ}$ & $\vec{n}$ & $\stackrel{m}{m}$ & 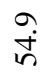 & $\begin{array}{l}0 \\
\stackrel{\text { I }}{工}\end{array}$ & $\Xi$ & $\Xi$ & $\stackrel{\sim}{\infty}$ \\
\hline $\begin{array}{l}\text { Winter } \\
\text { barley } \\
\text { for } \\
\text { mustard }\end{array}$ & $\begin{array}{l}o \\
\stackrel{i}{C}\end{array}$ & $\frac{9}{n}$ & $\stackrel{i}{\infty}$ & बें & $\underset{i}{\stackrel{P}{r}}$ & $\stackrel{?}{r}$ & $\stackrel{0}{\stackrel{1}{n}}$ & $\stackrel{\infty}{\grave{\lambda}}$ & 0 & $\stackrel{8}{8}$ & $\stackrel{\stackrel{f}{0}}{\circ}$ & 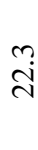 \\
\hline
\end{tabular}


Table 5. Productive moisture reserves in links of crop rotations in second rotation during sowing, $\mathrm{mm}$.

(a)

\begin{tabular}{|c|c|c|c|c|c|c|c|c|c|c|c|c|}
\hline \multirow[b]{2}{*}{$\begin{array}{l}\text { Crop } \\
\text { rotation } \\
\text { links }\end{array}$} & \multicolumn{2}{|c|}{2011} & \multicolumn{2}{|c|}{2012} & \multicolumn{2}{|c|}{2013} & \multicolumn{2}{|c|}{2014} & \multicolumn{2}{|c|}{2015} & \multicolumn{2}{|c|}{ Average } \\
\hline & $\frac{0}{1}$ & $\frac{8}{1}$ & $\stackrel{0}{1}$ & $\frac{8}{1}$ & $\stackrel{0}{1}$ & $\frac{8}{1}$ & $\stackrel{0}{\frac{1}{0}}$ & $\frac{8}{0}$ & $\stackrel{0}{1}$ & $\frac{8}{1}$ & $\frac{0}{1}$ & $\frac{8}{3}$ \\
\hline \multicolumn{13}{|c|}{ Crop rotation I } \\
\hline $\begin{array}{l}\text { Winter } \\
\text { wheat in } \\
\text { pure } \\
\text { fallow }\end{array}$ & $\stackrel{n}{ \pm}$ & $\begin{array}{l}\stackrel{\circ}{a} \\
\text { a }\end{array}$ & $\underset{\infty}{\infty}$ & $\bar{g}$ & 0 & 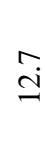 & $\stackrel{n}{=}$ & $\stackrel{m}{2}$ & $\underset{0}{8}$ & 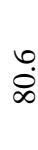 & $\begin{array}{l}\infty \\
\infty \\
\infty\end{array}$ & iু \\
\hline Mustard & $\stackrel{?}{\varrho}$ & $\hat{\&}$ & $\begin{array}{l}\infty \\
\infty \\
\infty\end{array}$ & in & $\overrightarrow{0}$ & $\begin{array}{l}r \\
\infty \\
i\end{array}$ & $\exists$ & $\begin{array}{l}\infty \\
\stackrel{0}{\circ}\end{array}$ & $\widehat{\check{I}}$ & $\begin{array}{l}\text { : } \\
\stackrel{8}{ }\end{array}$ & $\hat{0}$ & $\overrightarrow{2}$ \\
\hline $\begin{array}{l}\text { Winter } \\
\text { wheat for } \\
\text { mustard }\end{array}$ & $\stackrel{?}{ \pm}$ & $\stackrel{े}{\circ}$ & $\begin{array}{l}\stackrel{8}{8} \\
\dot{n}\end{array}$ & $\vec{\sim}$ & 0 & 0 & $\stackrel{\sim}{\stackrel{0}{0}}$ & $\begin{array}{r}+ \\
i n\end{array}$ & \&̊ & $\stackrel{+}{\stackrel{\infty}{\infty}}$ & 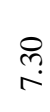 & $\stackrel{\circ}{\circ}$ \\
\hline
\end{tabular}

(b)

\begin{tabular}{|c|c|c|c|c|c|c|c|c|c|c|c|c|}
\hline \multirow{2}{*}{$\begin{array}{l}\text { Crop } \\
\text { rotation } \\
\text { links }\end{array}$} & \multicolumn{2}{|c|}{2011} & \multicolumn{2}{|c|}{2012} & \multicolumn{2}{|c|}{2013} & \multicolumn{2}{|c|}{2014} & \multicolumn{2}{|c|}{2015} & \multicolumn{2}{|c|}{ Average } \\
\hline & $\frac{0}{1}$ & $\frac{8}{1}$ & $\frac{0}{1}$ & $\frac{8}{1}$ & $\frac{0}{0}$ & $\frac{8}{1}$ & $\frac{0}{0}$ & $\frac{8}{1}$ & $\frac{0}{1}$ & $\frac{8}{1}$ & $\frac{0}{1}$ & $\frac{8}{0}$ \\
\hline \multicolumn{13}{|c|}{ Crop rotation II } \\
\hline $\begin{array}{l}\text { Fallow } \\
\text { winter } \\
\text { wheat }\end{array}$ & $\stackrel{9}{=}$ & $\begin{array}{l}\infty \\
\stackrel{\infty}{\infty}\end{array}$ & $\underset{\infty}{\stackrel{\infty}{\infty}}$ & $\stackrel{a}{\infty}$ & 0 & 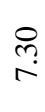 & $\stackrel{n}{=}$ & 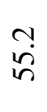 & $\stackrel{\circ}{=}$ & $\begin{array}{l}\stackrel{\nabla}{\circ} \\
\stackrel{\circ}{n}\end{array}$ & 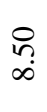 & $\stackrel{\check{\gamma}}{\vec{\gamma}}$ \\
\hline Mustard & $\frac{0}{a}$ & $\frac{n}{\infty}$ & $\begin{array}{l}\underset{.}{8} \\
\text { in }\end{array}$ & ले & ণิ & $\begin{array}{l}\infty \\
\infty \\
i \\
i n\end{array}$ & $\stackrel{\infty}{\stackrel{0}{\varrho}}$ & $\stackrel{\infty}{\infty}$ & $\hat{\mathrm{I}}$ & $\begin{array}{l}\stackrel{+}{\circ} \\
\stackrel{2}{ }\end{array}$ & 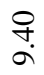 & $\stackrel{?}{?}$ \\
\hline $\begin{array}{l}\text { Winter } \\
\text { barley for } \\
\text { mustard }\end{array}$ & $\hat{0}$ & ڤे & 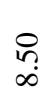 & n? & 0 & 0 & $\stackrel{n}{=}$ & $\stackrel{0}{\vec{\forall}}$ & n̊? & $\begin{array}{l}0 \\
\stackrel{8}{8}\end{array}$ & $\frac{0}{\infty}$ & $\stackrel{\infty}{\dot{\gamma}}$ \\
\hline
\end{tabular}


The presence of productive moisture for sowing winter wheat by pure fallow in rotation I in the meter layer is $17.1 \mathrm{~mm}$ higher than by fallow occupied by legumes. The reserves of moisture available to plants for sowing mustard after winter wheat in clean and occupied fallow, both in the sowing layer and in the meter layers, are at the same level. The amount of moisture for winter crops, which is the fourth crop in the first crop rotation with pure fallow is $30 \mathrm{~mm}$, with occupied one is $22.3 \mathrm{~mm}$.

In the second rotation, the moisture conditions were more severe than in the first one. The reserves of productive moisture for the studied crops during sowing were higher in the crop rotation with pure fallow, in comparison with the crop rotation with fallow occupied by 63.6 and 53.3 , respectively.

When harvesting the listed crops of crop rotation, on average, over 10 years of research, there was no moisture in the 0 to $10 \mathrm{~cm}$ layer, and in the meter layer either there was no moisture $(2010,2013)$ or was less than $10 \mathrm{~mm}$.

Agrophytocenosis consists of two blocks of plants: cultivated and weed, while if the cultivated plant in the field is most often represented by one species, then the weed community is multi-species. The number of weeds depends on many factors, the main one being the competitiveness of cultivated plants. An integral part of modern plant protection against weeds is a carefully planned crop rotation, and only then a chemical control method, which is characterized by high technical efficiency, mobility, but still poses a certain threat to the environment [22-23].

In our experiments, while observing crop rotations, sowing dates and sowing density, which is very important in the formation of a competitive herbage of cultivated plants, both mechanical and chemical methods of weed control were used.

Weeds in mustard crops were mainly represented by ephemeral and early spring crops: spiny-leaved chickweed (Cerastium perforatum), Tatar buckwheat (Fagopyrum tataricum L.), ivy-leaved veronica (Veronica hederifolia L.), garden purslane (Portulaca L.) there were single specimens of a root- sprouting perennial - field bindweed (Convolvulus arvensis L.). Winter crops are infested mainly with spring annuals and winter crops, which have a development cycle like winter cereals. The ratio between wintering and spring weeds is about one to three. Rhizomatous and root-sprouting perennials in winter crops were not observed, after two rotations of crop rotation, field bindweed in mustard crops was also not observed.

In the year the stationary experiment was laid, weediness for all crops of the crop rotation was rather high (Table 6). Thanks to the strict observance of the alternation of crops in crop rotations, all the provided agrotechnical and chemical methods of weed control, their number decreased several times by the end of the second rotation. The greatest reduction in weeds was recorded in wheat crops for pure fallow - by 8 times and in subsequent mustard crops - by 6 times, for other links of crop rotation - by 3 to 4 times. The greatest loss of weeds was noted in winter wheat crops for pure fallow $-87 \%$ and in the subsequent sowing of mustard $-82 \%$, for other links of crop rotation - 70 to $75 \%$. 
Table 6. Weediness by links of crop rotation in year of station establishing and after 10 years, $\mathrm{pcs} / \mathrm{m}^{2}$.

\begin{tabular}{|c|c|c|c|}
\hline Crop & 2006 & 2015 & Weed death, \% \\
\hline \multicolumn{3}{|c|}{ Crop rotation I } \\
\hline Winter wheat, precursor is pure fallow & 180 & 23.0 & 87.0 \\
\hline Mustard & 95.0 & 17.0 & 82.0 \\
\hline \multicolumn{2}{|c|}{ Crop rotation II } \\
\hline $\begin{array}{c}\text { Winter wheat for mustard } \\
\text { fallow }\end{array}$ & 222 & 46.0 & 75.0 \\
\hline Mustard & 70.0 & 21.0 & 75.0 \\
\hline $\begin{array}{c}\text { Winter wheat, precursor is occupied } \\
\text { Winter barley, precursor is mustard }\end{array}$ & 145 & 41.0 & 70.0 \\
\hline
\end{tabular}

\section{Conclusion}

1. Analysis of the yield by crop rotation with the title field of pure fallow and occupied fallow showed that for the first rotation, an average yield of Sarepta mustard was 1.30 and $1.20 \mathrm{t} / \mathrm{ha}$, respectively. White mustard in the second rotation had an average yield in a crop rotation with a pure fallow of 1.10 , and with a fallow of $1.00 \mathrm{t} / \mathrm{ha}$. It follows from this that in the crop rotation with pure fallow, there was a tendency to increase the yield by $0.1 \mathrm{t} / \mathrm{ha}$ in comparison with the crop rotation.

2. The reserves of productive moisture for sowing mustard were the same in crop rotations with the header field of pure fallow and occupied one: in the sowing layer are 10.9 and 10.2; in meter layer are 83.6 and $78.0 \mathrm{~mm}$.

3 . The number of weeds in two rotations decreased - the death of weeds by crops ranged from 70.0 to $87.0 \%$.

\section{References}

1. Nikolaev E V, Izotov A M, Tarasenko B A 2006 Plant growing of the Crimea (Simferepol: Factor)

2. Nikolaev E V 2004 Scientific justification of the main directions of development of an agroindustrial complex of the Crimea (Simferopol: Tavria)

3. Bai H Q, Wang J, Fang Q X, Huang B X 2020 Does a trade-off between yield and efficiency reduce water and nitrogen inputs of winter wheat in the North China Plain? Agricultural water management (4)233 095-106/ doi: 10.1016/j.agwat.2020.106095

4. Spiess E, Humphrys C, Richner W, Schneider M K, Piepho H P, Chervet A, Prasuhn V 2020 Does no-tillage decrease nitrate leaching compared to ploughing under a longterm crop rotation in Switzerland? Soil \& Tillage research 5(199) 104-115/ doi: 10.1016/j.still.2020.104590

5. Klepinin N N 1927 How the Crimean experimental station works (Simferopol: Krymgosizdat)

6. Gavrilyuk M M 2012 Oil crops in Ukraine (Kiev: Osnova)

7. Jankowski K J, Zaluski D, Sokolski M 2020 Canola-quality white mustard: Agronomic management and seed yield industrial crops and products Industrial crops and products 5(145) 112-138 doi: 10.1016/j.indcrop.2020.112138

8. Rana K, Parihar M, Singh J P, Singh R K 2020 Effect of sulfur fertilization, varieties and irrigation scheduling on growth, yield, and heat utilization efficiency of indian mustard (Brassica Juncea L.) Communications in soil science and plant analysis 2(51) 265-275 doi: 10.1080/00103624.2019.1705325 
9. Zhang Y, Xie D T, Ni J P, Zeng X B 2019 Optimizing phosphate fertilizer application to reduce nutrient loss in a mustard (Brassica juncea var. tumida)-maize (Zea mays L.) rotation system in Three Gorges Reservoir area Soil \& Tillage research 7(190) 78-85 doi: 10.1016/j.still.2019.03.001

10. Kayacetin F, Onemli F, Yilmaz G, Khawar K M, Kinay A, Hatipoglu H, Kivilcim M N, Kara N, Kose A, Sefaoglu F 2019 Growing degree day and seed yield relationships in mustard (Brassica juncea L.) under different sowing seasons and locations of Turkey Journal of agricultural sciebces-tarim bilimleri dergisi 3(25) 298-308

11. Kulintsev V V, Godunova E I, Zhelnakova L I 2013 New-generation farming systems of the Stavropol Territory: monograph (Stavropol: Argus)

12. Lukomets V M, Gorlov N M, Tishkov S L 2015 Prospective resource-saving technology for mustard production (Moscow: Agroizdat)

13. Pashtetsky V S, Radchenko L A, Turina E L, Verdysh M V 2016 Technology of growing mustard and camelina in Crimea (Simferopol: Tavrida)

14. Mhatre S, Rajaraman P, Chatterjee N, Bray F, Goel M, Patkar S, Ostwal V, Patil P, Manjrekar A, Shrikhande S V 2020 Mustard oil consumption, cooking method, diet and gallbladder cancer risk in high- and low-risk regions of India International journal of cancer 4(266) 96-104 doi: 10.1002/ijc.32952

15. Bahmid N A, Pepping L, Dekker M, Fogliano V, Heising J 2020 Food chemistry 3(308) 112-120. doi: 10.1016/j.foodchem.2019.125573

16. Nikolaev E V, Nazarenko L G, Melnikov M M 2016 Crimean field farming: a reference guide on agricultural technology for growing field crops (Simferopol: Tauris)

17. Pashtecky V S 2016 A scientifically based development strategy for the agricultural sector of Crimea until 2020: a collective monograph (Simferopol: Arial)

18. Dragan N A 2013 Soil of Crimea (Simferopol: SSU)

19. Adamenko T I 2011 Agroclimatic reference book (Simferopol: Tauris)

20. Dospekhov B A 2011 Methods of field research (Moscow: Agropromizdat)

21. Little T, Hills F 1981 Agricultural pilot business. Planning and analysis (Moscow: Kolos)

22. Lopes-da-Silva M, Martins O M, Wulff N A, Ichida C M, Guimaraes A S, Guimaraes G C, Sanches M M 2020 Survey of 16SrIX phytoplasmas associated with HLBsymptoms in weeds and leafhoppers at citrus orchards Tropical plant pathology 5(203) 1122-1130 doi: 10.1007/s40858-020-00345-w

23. Podgorny P I 2016 Crop production (Moscow: Agroizdat) 